\title{
Enantiomers of Carbohydrates and Their Role in Ecosystem Interactions: A Review
}

\author{
Lea Lojkova ${ }^{1}$, Valerie Vranová ${ }^{2}$, Pavel Formánek ${ }^{3}$ (C) Ida Drápelová ${ }^{4}$, Martin Brtnicky ${ }^{5,6}$ (D) and \\ Rahul Datta $5, *$ (D) \\ 1 Department of Chemistry and Biochemistry, Faculty of Agriculture, Mendel University in Brno, \\ Zemědělská 1, 61300 Brno, Czech Republic; lea.lojkova@mendelu.cz \\ 2 Department of Geology and Soil Science, Faculty of Forestry and Wood Technology, Mendel University in \\ Brno, Zemědělská 3, 61300 Brno, Czech Republic. valerie.vranova@mendelu.cz \\ 3 Research Institute for Soil and Water Conservation, Žabovřeská 250, 15627 Praha 5-Zbraslav, \\ Czech Republic; pavel.formanek@gmail.com \\ 4 Faculty of Forestry and Wood Technology, Dean office, Mendel University in Brno, Zemědělská 3, \\ 61300 Brno, Czech Republic. ida.drapelova@mendelu.cz \\ 5 Department of Agrochemistry, Soil Science, Microbiology and Plant Nutrition, Faculty of AgriSciences, \\ Mendel University in Brno, Zemedelska 1, Brno 61300, Czech Republic. martin.brtnicky@mendelu.cz \\ 6 Institute of Chemistry and Technology of Environmental Protection, Brno University of Technology, \\ Faculty of Chemistry, Purkynova 118, 62100 Brno, Czech Republic \\ * Correspondence: rahulmedcure@gmail.com or rahul.datta@mendelu.cz; Tel.: +420-773-990-283
}

Received: 6 February 2020; Accepted: 12 March 2020; Published: 17 March 2020

check for updates

\begin{abstract}
D- and most L-enantiomers of carbohydrates and carbohydrate-containing compounds occur naturally in plants and other organisms. These enantiomers play many important roles in plants including building up biomass, defense against pathogens, herbivory, abiotic stress, and plant nutrition. Carbohydrate enantiomers are also precursors of many plant compounds that significantly contribute to plant aroma. Microorganisms, insects, and other animals utilize both types of carbohydrate enantiomers, but their biomass and excrements are dominated by D-enantiomers. The aim of this work was to review the current knowledge about carbohydrate enantiomers in ecosystems with respect to both their metabolism in plants and occurrence in soils, and to identify critical knowledge gaps and directions for future research. Knowledge about the significance of D- versus L-enantiomers of carbohydrates in soils is rare. Determining the mechanism of genetic regulation of D- and L-carbohydrate metabolism in plants with respect to pathogen and pest control and ecosystem interactions represent the knowledge gaps and a direction for future research.
\end{abstract}

Keywords: carbohydrate enantiomers; plant metabolism; soil microorganisms; transgenic plants; pests and pathogens; cellulose; hemicelluloses; and lignin

\section{Introduction}

Carbohydrates play a central role in cell metabolism and are a primary product of photosynthesis. They belong to the most abundant organic compounds of terrestrial ecosystems and are used in chemical research [1-3]. Carbohydrates enter the ecosystems by means of dry deposition, rainfall, throughfall, and especially through stemflow [4,5]. Leaching of carbohydrates from vegetation is of significance in sites loaded by acid deposition. Neutral sugars have been identified and analyzed in aerosols at urban and forested suburban sites, where glucose and mannose were found to be dominant [6]. Carbohydrates are precursors for the synthesis of many biochemically active compounds and are important in terms of interactions between organisms of different trophic levels, having 
great significance for plant nutrition and phytoremediation [7]. Glucose, xylose, arabinose, galactose, rhamnose, and uronic acids represent the dominant carbohydrates of plant and animal tissues (Table 1).

Table 1. Dominant carbohydrates of plants.

\begin{tabular}{|c|c|c|c|}
\hline Plant/Animal & Type of Material & Dominant Carbohydrate & References \\
\hline Acacia sp. & Water-extract & Galactose & [8] \\
\hline Algea & Exopolysaccharides & $\begin{array}{l}\text { Glucose, arabinose, mannose, } \\
\text { rhamnose, galactose and xylose }\end{array}$ & [9] \\
\hline Aromatic plants & Leaves & Glucose, fructose & [10] \\
\hline Banana plants & Petioles & Arabinose, galactose, glucose & [11] \\
\hline Beech, Oak & Litter & Xylose, glucose, galactose, arabinose & [12] \\
\hline Canavalia sp. & Fiber & Uronic acid, glucose, arabinose & [13] \\
\hline Cannamonum sp. & Extracted polysaccharide & Mannose, galactosamine & [14] \\
\hline Chorisia speciosa & Seed coat & Galactose & [15] \\
\hline Cochlospermum gossipium & Gum & Uronic acid & [16] \\
\hline Cordia abyssinica & Fruits & Galactose, rhamnose & {$[17]$} \\
\hline Corn & Litter & Xylose, glucose & [18] \\
\hline Cryptomeria japonica & Xylem & Glucose, galactose, xylose and fucose & [19] \\
\hline \multirow[t]{2}{*}{ Different plants } & Gums & Arabinose, galactose & {$[20]$} \\
\hline & Seed mucilage & Maltose & \\
\hline Eucalyptus sp. & Wood & Glucose & {$[21]$} \\
\hline Grassland community & Leaves & $\begin{array}{l}\text { Arabinose, xylose, mannose, } \\
\text { arabinose and glucose }\end{array}$ & [22] \\
\hline Transgenic plants & Cell walls & Glucose, xylose & [23] \\
\hline
\end{tabular}

The ability of carbon atoms to form chiral structure is the basis of living systems on the Earth [24]. In several studies, chirality has been considered in terms of a branching index [25,26]. L- and D-enantiomers of carbohydrates occur naturally and have different roles in different organisms: L-mannose and L-rhamnose, bacterial polysaccharides and mucilages (gellan, welan, rhamsan); L-arabinose such as plant gums and bacterial polysaccharides; D-arabinose, aloe glycosides; D-rhamnose, a capsid of Gram-negative bacteria; D-fucose, cardiac glycosides and resins of trees; and L-fucose in blood group substances [27]. Sharp decline in soil nutrient (carbohydrate, soil carbon and soil nitrogen) across ecotone is also reported in some research [28,29]. The present review paper summarizes the knowledge on enantiomers of carbohydrates in terrestrial ecosystems, their role in ecosystem interactions, and highlights important areas for future research.

\section{D- and L-Carbohydrates of Plants}

Cellulose, hemicelluloses, and lignin represent the major biochemical components of plants [30]. Carbohydrates form up to $93 \%$ of plant dry weight and have many roles in plants including building up biomass and carbon storage, being the precursor for the synthesis of many compounds including glycosides, saponins, glycoproteins, and acting as defense compounds against pathogens, herbivory, and abiotic stress [31-36].

\subsection{Role of Carbohydrates under Stress and Protection against Herbivory}

Osmolytes including carbohydrate are other neutral molecules that protect plants under various stress factors [37]. These metabolites include proline, sucrose, polyols, and trehalose (Figure 1), and they protect the plant under stress conditions by conserving the cellular function of plant. Many reports have suggested the role of osmolytes in drought [38], predator, and pesticide stress [39-41] Figure 2 represents the structure of some osmolytes. Accumulation of myo-inositol indicates membrane disintegration due to air pollution [42]. Pectic polysaccharide mucilage plays an important role in plant tolerance to salinity stress when it increases in stems, shoots, and roots with increased uronic acid and rhamnose [43]. Furthermore, flavonoid and chitinase gene expression are plant defense mechanism 
responses to insect herbivory [35]. Cyanogenic glycosides, a secondary metabolite of the plant, is composed of alpha-hydroxy nitrile and D-glucose moiety; these compounds are potentially dangerous to animals and humans due to the presence of hydrogen cyanide (HCN). Release of such substances occurs spontaneously or through enzymatic regulation by the plant.

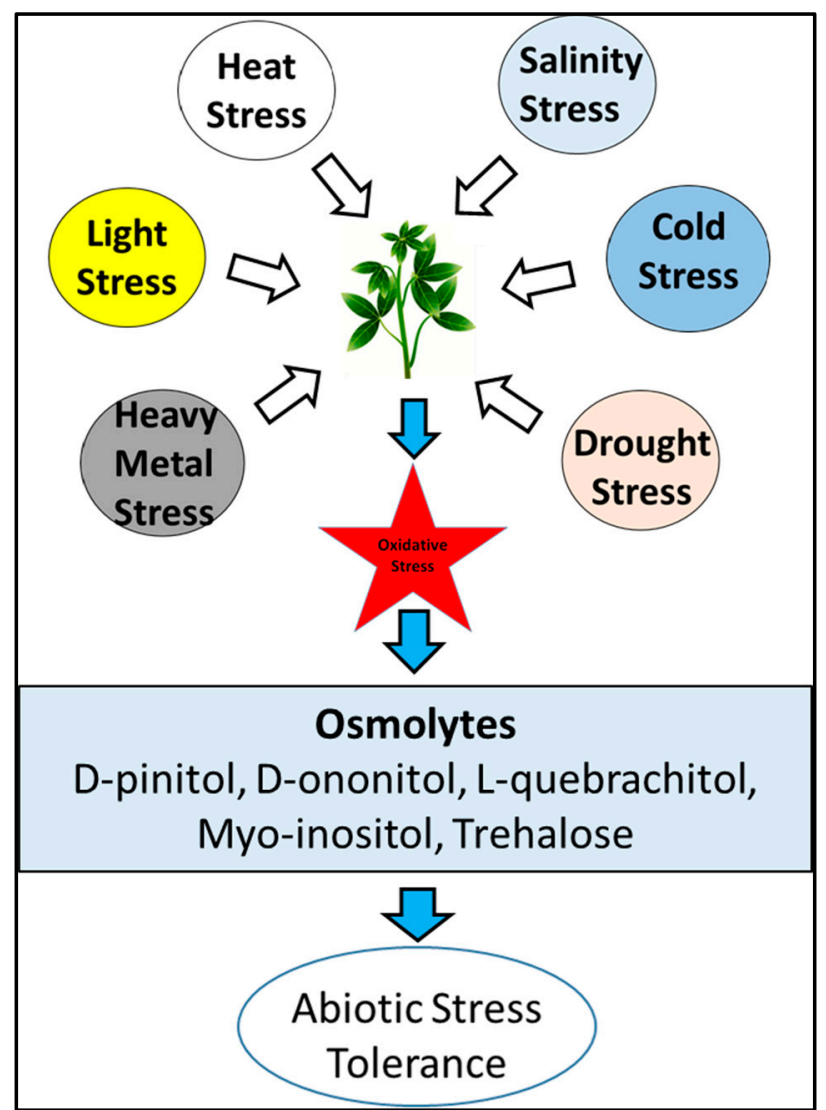

Figure 1. Schematic representation of the plant's response to various abiotic stresses and the role of osmolytes under stressful conditions [44].

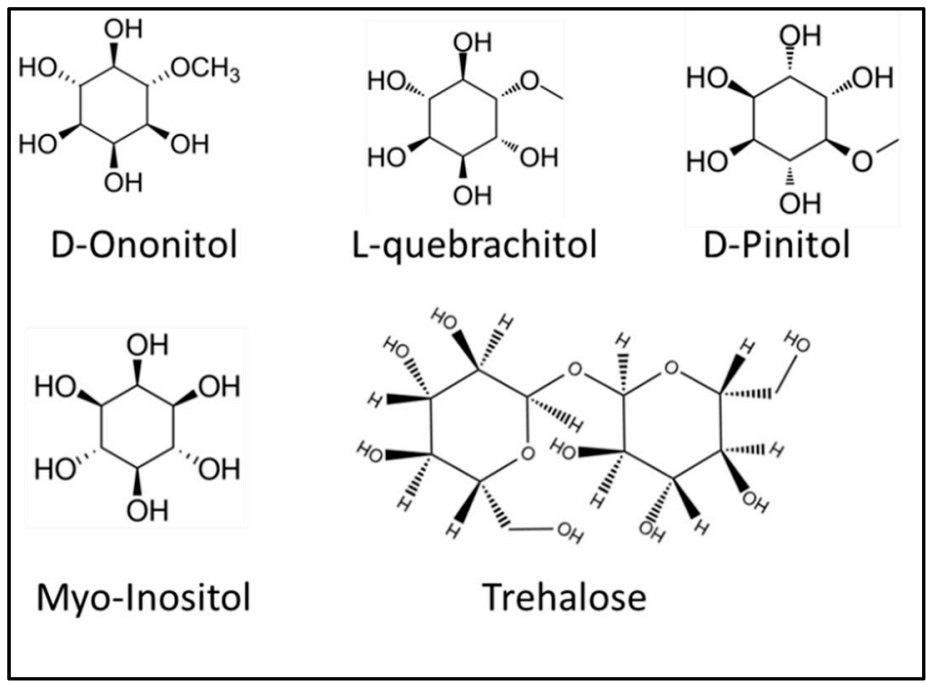

Figure 2. Structure of some carbohydrate origin osmolytes present in plants.

Cassava roots, rich in starch, acting as goitrogens (substances that disrupt the production of thyroid hormones by interfering with iodine uptake in the thyroid gland) [45]. The lectins (carbohydrates 
containing glycoproteins) of some plants (Croton triglium, Abrus precatorius, Robinia pseudoacacia) are toxic to humans and animals, leading to loss of appetite, decreased body weight, and death [46]. Soybean saponins protect plants from Callosobruchus chinensis, whereas higher animals are able to degrade these compounds [47]. Saponins exert a strong activity on lepidopteran cells, presumably based on a cytotoxic action due to permeation of the cell membrane [48]. Latex proteins of mulberry-silkworms inactivate chitinase and protect plants from insect herbivory [34]. Lecitin glycoproteins (3\% of carbohydrates) from Arisaema sp. have insecticidal properties [49]. Some plant $\beta$-glycosides (phlorizin, amygdalin or prunasin) inhibit trehalase, a key enzyme of glucose metabolism in insects [50].

Plant chlorogenic acid is an inhibitor of glucose-6-phosphate translocase [31]; it increases with nematode attack and other types of stress [51]. Furthermore, abiotic stress increases galactose and raffinose levels in the plants [36]. The significant role of carbohydrates like pinitol, ononitol, mannitol, and inositol has been proven in plant defense against Erwinia amylovora [52]. Increased expression of $\beta-1,3$ glucanases in flax increases resistance to fungi [53]. On the other hand, fructose of exuded tree sap was found to stimulate the growth of all tested saprophagous butterflies, whereas the glucose feeding stimulatory effect was found only for some [51]. The galactinol synthase (which occurs in three isoforms) gene (CaGolS1-2-3), which catalysis the raffinose family of carbohydrates in plants, is upregulated by abiotic stress [54]; the gene has been cloned [55].

The above findings summarize that abiotic and biotic stress factors alter the carbohydrate metabolism of plants. However, the mechanisms of the alterations are not fully understood [56]. Carbohydrates have cryoprotective and osmoregulatory properties they accumulate under salt stress or pathogen attack (sucrose, pinitol), or act as reactive oxygen species scavengers including contribution to membrane stabilization via reaction with phospholipid headgroups (as reported for raffinose) increasing chilling tolerance [34]. On the other hand, pollutants such as Ozone, Sulfur dioxide, and Nitrogen Oxides are hypothesized to cause de-esterification of membrane lipids, leading to increased concentrations of free carbohydrates such as myo-inositol [43]. Only a few plant proteins are known to inactivate enzymes of the carbohydrate metabolism of some insects, and more research is necessary to understand the mechanism and adaptation of plant defense against herbivory [34].

\subsection{Occurrence $O f D$ - and L-Carbohydrates, Their Metabolism in Plants, and Its Genetic Regulation}

The plant contains several Levo form of carbohydrates like L-arabinose, L-fucose, L-rhamnose, and L-galactose. The carbohydrate content of the plant is not fixed and changes from season to season [57]. Most plant carbohydrates are generated by the sequential conversion of UDP-D-glucose, whereas L-fucose and L-galactose in plants are derived from GDP-D-mannose. L-fucose formation requires the presence of enzyme GDP-D-mannose-4,6-dehydratase (GMD) and GDP-4-keto-6-deoxy-dmannose-3,5-epimerase-4-reductase (GER), whereas, on the other hand, GDP-L-galactose is formed by the GDP-D-mannose 3,5-epimerase (GME) enzyme [58,59]. Plants synthesize UDP-sugar by an enzyme encoded by gene RHM that leads to the conversion of UDP-D-glucose into UDP-L-rhamnose [58]. UDP-D-glucose can be directly converted into UDP-D-galactose, UDP-D-glucuronic acid, or UDP-L-rhamnose. GDP-D-mannose can be converted into GDP-L-fucose by the action of enzyme GDP-D-mannose-4,6-dehydratase, or it can also be converted into GDP-L-galactose and GDP-L-glucose by enzyme GDP-D-mannose 3,5-epimerase. Pyrophosphatases and phosphatase enzymes catalyze the formation of either L-glucose or from UDP-L-glucose or L-galactose from UDP-L-galactose [59].

L-galactose is the starting material of ascorbic acid L-synthesis. N-methyl cyclopropane acts as an inhibitor of ascorbate synthesis from L-galactose [60]. Conversion of D-mannose to L-galactose is a limiting step of L-ascorbic acid synthesis. UDP-xylose is produced via catalysis by UDP-glucuronate decarboxylase [61]. The formation of xylans is accompanied by cross-linkages with lignin via alpha-L-arabinofuranosyl residues [62]. Methyltransferase involved in the formation of 4-O-methylglucuronoxylan in pea epicotyl is stimulated by UDP-D-xylose and UDP-D-glucuronic acid [63]. UDP-glucose dehydrogenase converts UDP-glucose to UDP-glucuronic acid, a precursor of 
many sugars. The enzyme is inhibited by UDP-xylose; a multifunctional carbohydrate L-myo-inositol is produced from D-glucose-6-P via L-myo-inositol-1-P [64].

The genes StUGE45 and StUGE51 encoding UDP-glucose-epimerases, which catalyze the conversion of UDP-glucose to UDP-galactose, were isolated from potato tubers [51]. The genes PpARF1 and PpARF/XYL, encoding alpha-L-arabinofuranosidase or alpha-L-arabinofuranosidase/ beta-D-xylosidase, respectively, were identified in peach [65]. L-rhamnose is a major constituent of the pectic polysaccharides of Arabidopsis cell walls and is synthesized by three enzymes including the rhamnose synthase, which is encoded by AtRHM1, AtRHM2/AtMUM4, and AtRHM3 [66]. Two Arabidopsis genes, At1g45130 and At3g52840, encode for beta-galactosidase isozymes. [66,67]. Apoplastic beta-xylosidase and beta-glucosidase of Arabidopsis are encoded by the same gene AtXYL1 [68].

Hemicelluloses contain D-xylose, L-arabinose, D-mannose, D-glucose, and D-galactose, and small amounts of L-rhamnose and L-fucose. The glucuronoxylans of hardwood contain a small amount of L-rhamnose, while the arabinoglucuronoxylan of non-woody (agricultural crops) contains L-arabinose when the linear B-(1,4)-D-xylopyranose backbone is linked by the $\alpha-(1,2)$ and $\alpha-(1,3)$ glycosidic bond with 4-O-methyl- $\alpha$-D-glucopyranosyl uronic acid and $\alpha$-L-arabinofuranosyl [69].

Glucuronoarabinoxylan is the most abundant hemicellulose of corn stover. Xyloglucans predominant in hemicelluloses of primary cell walls of grasses contain large amounts of D-glucose, D-xylose as well as L-arabinose and L-fucose [2]. Xyloglucans of bilberries (an important crop of northern Europe) contain D-xylose and galactose plus L-fucose, the building blocks contain galactose-xylose and fucose-galactose-xylose side chains with acetylated galactose [70]. Xyloglucans of gymnosperm walls have D-carbohydrates predominantly and are similar to eudicotyledons and monocotyledons in also containing L-arabinose [71]. Arabinoxylans, major hemicelluloses of cereal cell walls, show higher L-arabinose content than hardwood xylans [69]. The xylan content of different tree species may reach up to $20 \%$ of dry matter [72] when they consist of a backbone of $\beta-1,4$-linked D-xylose residues containing side groups such as L-arabinose, D-galactose, or D-(4-O-methyl)-glucuronic acid [73].

Plant pectin contains D-galacturonate with a small amount of L-arabinose, D-galactose, and L-rhamnose [74]. L-galactose is essential for L-ascorbic acid synthesis with L-glucose and L-galactonic acid as intermediates [75]. Plant glycoalkaloids, especially chaconine, solamargine, and solanine, contain L-rhamnose and L-galactose sugar [76], which forms a disaccharide, bis- $\alpha$-L-rhamnopyranosyl- $\beta$-D-glucopyranose or $\alpha$-L-rhamnopyranosyl- $\beta$-glucopyranosyl- $\beta$-Lgalactopyranose with $\beta$-D-glucose. Arabic gums (branched-chain, complex polysaccharides, either neutral or slightly acidic) contain L-arabinose and L-rhamnose in the form of $\alpha$-L-arabinofuranosyl and $\alpha$-L-rhamnopyranosyl [77].

The primary cell walls of lycophytes have a high concentration of 3-O-methyl-D-galactose [77] Both D- and L-galactose are synthesized from UDP-D-glucose (via UDP-galactose) when D-galactose is more abundant in plants. Separation of the enantiomeric forms showed the ratio of D-/L-galactose ranged from 7.3 to 70 , in the lycophytes or spinach cells when D-galactose oxidase oxidizes the $-\mathrm{CH} 2 \mathrm{OH}$ group of D- but not L-galactose [78,79].

L-galactose dehydrogenase is an important enzyme of phenolic compounds, tocopherol, and ascorbic acid synthesis in plants, and is the catalysis for the conversion of D-galactose to L-galactono-1,4-lactone [80].Galactose induces the gene for dammarenediol synthase CabAS of plants and accumulates due to some diseases such as huanglongbing of citrus plants [81]. Galactose is toxic to Albizzia sp. root explants and other tissues and induces the gene for flavonoid glucosyltransferase expression [66].

\subsection{Perspectives for Future Research}

An approach has been used to elucidate the role of nucleotide sugar interconverting enzymes for the regulation of cell wall synthesis, [58,61], but their expression, kinetic properties, and intracellular 
localization or modification of cell wall pectic polysaccharides are still poorly understood $[67,82]$. Research on transgenic plants is also targeted to reduce the content of some types of carbohydrates. The use of endogenous gene expression was reported to reduce the carbohydrate content of some transgenic plants (potato) or decrease rhamnogalacturonan by ectopic expression of rhamnogalacturonan lyase from Aspergillus sp. [83].

Many works deal with the metabolism of carbohydrates and ascorbic acid in plants $[60,64,65,75]$, but its regulation and multifunctional role of some carbohydrates (e.g., myo-inositol) are still poorly understood. Moreover, many genes of carbohydrate transporters were not identified including factors regulating their expression and localization. In particular, biosynthesis control and the interplay of enantiomeric forms or phosphorylative processes represent knowledge gaps of the genes encoding enzymes included in carbohydrate metabolism [64]; only part has been functionally characterized [67]. Better understanding the action of plant hydrolytic enzymes involved in carbohydrate metabolism gives promise for industrial applications including the paper industry, preparation of animal feed, fabrication of sugar beet syrup, etc. with the replacement of microbially-derived enzymes [64]. Additionally, some plant biopharmaceuticals are glycoproteins produced through Golgi N-glycosylation [84].

\section{Significance of Enantiomers of Carbohydrates for Invertebrates and Vertebrates}

Insects and other animals assimilate both L- and D-carbohydrates [85]. Carbohydrates represent a major contributor to all trophic categories of insects with no or only a low contribution from the degradation of lignin [7]. Protophormia terraenovae is commonly called the northern blowfly, blue-bottle fly, or blue-assed fly. It is distinguished by its deep blue coloration and large size. Carbohydrate enantiomers act differently on the salt receptors of Protophormia terraenovae; L-fucose has a stronger stimulatory effect than D-fucose $[86,87]$. Polysaccharides have taxonomic significance for parasitology including the evolutionary line of Crithidia sp. [88].

L-fucose as well as some D-carbohydrates inhibits agglutination of rabbit erythrocytes [89]; L-arabinose and D-galactose, D-maltose, D-psicose, D-xylose, neuraminyl lactose and neuraminyl-Nacetyl-lactosamine or 1,5-anhydro-D-glucitol and enzymes (e.g., $\beta$-galactosyltransferase or $\mathrm{N}$-acetyl$\alpha$-D-glucosaminidase) occur in the urine [90]. The ratio of $\mathrm{L} / \mathrm{D}$ carbohydrates serves as an indicator of human diseases (i.e., the ratio of $\mathrm{D} / \mathrm{L}$ arabinitol in cerebrospinal fluids (range: $8.6-2.8$ ) indicates Candida infections [91]. Absorption of L-glucose in human intestines is higher than L-galactose or L-mannose and D-mannitol [92].

\section{L- and D-Carbohydrates in Soil}

Information about soil carbohydrates including the effects of management practices was reviewed by Vranova et al. (2013) [93]. Little knowledge exists about the enantiomers of carbohydrates in soil, both L-and D-carbohydrates occur in composts and humic substances in a ratio of 0.07 to 0.13 (Table 2) [94]. Aside from plant and animal biomass, L-carbohydrates enter soils from different sources including medical colon-cleansing agents, which enter soil through urine and feces [95]. 
Table 2. Ratio of L- versus D-carbohydrates in different materials.

\begin{tabular}{|c|c|c|c|c|}
\hline Plant/Organism & Material & $\begin{array}{c}\text { L/D } \\
\text { Carbohydrates }\end{array}$ & $\begin{array}{c}\text { Dominant } \\
\text { Carbohydrates }\end{array}$ & References \\
\hline American larch & $\begin{array}{l}\text { Arabinogalactans } \\
\text { of wood }\end{array}$ & 6 & $\begin{array}{l}\text { D-galactose, } \\
\text { L-arabinose }\end{array}$ & [96] \\
\hline $\begin{array}{l}\text { Cochlospermum } \\
\text { religiosum }\end{array}$ & $\begin{array}{l}\text { Heteropolysaccharides } \\
\text { from gum }\end{array}$ & 1 & $\begin{array}{c}\text { L-rhamnose, } \\
\text { D-galactose, } \\
\text { D-galacturonic acid }\end{array}$ & [97] \\
\hline Dalbergia sissoo & $\begin{array}{c}\text { Acid } \\
\text { polysaccharide }\end{array}$ & 0.16 & $\begin{array}{c}\text { L-rhamnose, } \\
\text { D-glucose, D-galactose }\end{array}$ & [98] \\
\hline Human & Urine & 0.13 & D-glucose, L-fucose & {$[99,100]$} \\
\hline Rat & Feces & 0.5 & D-galactose, L-fucose & [101] \\
\hline Soil & Humic substances & 0.13 & D-glucose, L-fucose & [94] \\
\hline Composts & - & $0.07-0.09$ & D-glucose, L-fucose & [94] \\
\hline Pseudotsuga menziesii & Bark holocellulose & 0.04 & L-arabinose, D-glucose & [102] \\
\hline
\end{tabular}

L-arabinose, L-rhamnose, and L-fucose are commonly included in soil respiration tests because these sources are found in substrates that are highly correlated with the metabolic diversity of the soil microbial community [103,104]. Plant species composition affects L-rhamnose utilization in the rhizosphere with the highest utilization rate for wheat [105]. Utilization of L-rhamnose is also significantly negatively correlated with microbial diversity of regenerated forest sites or rhizosphere [106]. Utilization of L-rhamnose (and D-galactose, $\mathrm{m}$-inositol, D-psicose) by the rhizosphere soil microbial community decreases with plant age [107,108]. D-xylose is used as a biostimulator of the microbial consortium for the degradation of pollutants [109].

Decomposition of Fraxinus excelsior leaves increases the proportion of glucose to other monosaccharides [110] when soil $\alpha$-glucosidase is slightly inhibited or activated by some L- and D-carbohydrates including L-arabinose and L-rhamnose, D-xylose, D-mannose or D-glucose [111]. Additionally, D-imino sugars and some amino acids such as 3- or 4-hydroxyproline are glycosidase inhibitors [112,113].

Overall, works published on carbohydrates and their microbial metabolism indicate that D- versus L-carbohydrates play different roles in soils. In particular, the inhibition/stimulation of soil enzymes ( $\alpha$-glucosidase, glycosidases) differ with respect to the type of carbohydrate enantiomers. Generally, L-carbohydrates are less inhibitory to $\alpha$-glucosidases compared to D-enantiomers; especially with the addition of nutrients such as iron. Only L-carbohydrates increased $\alpha$-glucosidase activity [114-119]; the mechanism of this effect is not known yet.

\section{Conclusions}

Understanding the metabolism of carbohydrates in plants, their genetic regulation, and their use as an indicator of stress, pollution, and pest control represents a target of future research. Other potential future research includes the elucidation of the upregulation mechanisms of genes that are involved in carbohydrate synthesis and the inhibition of key enzymes of biochemical pathways. The use of plant breeding to regulate glycoalkaloids and carbohydrate inputs to the soil via rhizodeposition represents a future way to improve plant nutrient acquisition that increases the efficiency of phytoremediation and reduces the emissions of greenhouse gases. Development of transgenic plants is targeted to regulate carbohydrates and synthesis of carbohydrate-containing compounds used in the food and pharmaceutical industries. There is also a knowledge gap concerning the occurrence and significance of L- versus D-enantiomers of carbohydrates and carbohydrate-containing compounds in soil organic matter that affect nutrient cycling (e.g., inhibition of phosphatase activity) and interactions between different organisms [120].

Future research requires a detailed understanding of plant defense mechanisms against herbivory and pathogens via gene expression of plant carbohydrate metabolism. The search continues for 
effective inhibitors of trehaloses of insects, molluscans, and fungi to control pests and other harmful organisms, and to understand the formation of plant glycosylated compounds that are of potential danger for animals and humans.

Author Contributions: Conceptualization, L.L. and M.B.; Methodology, P.F., I.D., and V.V.; Validation V.V. and I.D.; Formal analysis, R.D.; Resources, M.B.; Data curation, L.L.; Writing-original draft preparation, L.L.; Writing-review and editing, R.D.; Visualization, R.D. and MB.; Supervision, P.F. and I.D.; All authors have read and agreed to the published version of the manuscript.

Funding: This research received no external funding.

Acknowledgments: This text was prepared within the framework of grant RO0218 supported by the Ministry of Agriculture of the Czech Republic.

Conflicts of Interest: The authors declare no conflicts of interest.

\section{References}

1. Boulineau, F.P.; Wei, A. Mirror-image carbohydrates: synthesis of the unnatural enantiomer of a blood group trisaccharide. J. Org. Chem. 2004, 69, 3391-3399. [CrossRef] [PubMed]

2. Kim, J.-S.; Lee, Y.-S. Effect of reaction $\mathrm{pH}$ on enolization and racemization reactions of glucose and fructose on heating with amino acid enantiomers and formation of melanoidins as result of the Maillard reaction. Food Chem. 2008, 108, 582-592. [CrossRef] [PubMed]

3. Padgett, P.E.; Cook, H.; Bytnerowicz, A.; Heath, R.L. Foliar loading and metabolic assimilation of dry deposited nitric acid air pollutants by trees. J. Environ. Monit. 2009, 11, 75-84. [CrossRef] [PubMed]

4. Hoffmann, D.; Tilgner, A.; Iinuma, Y.; Herrmann, H. Atmospheric Stability of Levoglucosan: A Detailed Laboratory and Modeling Study. Environ. Sci. Technol. 2010, 44, 694-699. [CrossRef] [PubMed]

5. Fang, G.-C.; Wu, Y.-S.; Chu, C.-C.; Huang, S.-H.; Rau, J.-Y. The concentration, dry deposition, composition study of ambient air particulate and metallic pollutants at a traffic sampling site. Toxicol. Ind. Health 2003, 19, 25-35. [CrossRef] [PubMed]

6. Tominaga, S.; Matsumoto, K.; Kaneyasu, N.; Shigihara, A.; Katono, K.; Igawa, M. Measurements of particulate sugars at urban and forested suburban sites. Atmos. Environ. 2011, 45, 2335-2339. [CrossRef]

7. Fuß, W. Biological homochirality as result from a single event. Colloids Surf. B Biointerfaces 2009, 74, 498-503. [CrossRef]

8. Aluwihare, L.; Repeta, D. A comparison of the chemical characteristics of oceanic DOM and extracellular DOM produced by marine algae. Mar. Ecol. Prog. Ser. 1999, 186, 105-117. [CrossRef]

9. Guimarães, R.; Barros, L.; Carvalho, A.M.; Sousa, M.J.; Morais, J.S.; Ferreira, I.C.F.R. Aromatic plants as a source of important phytochemicals: Vitamins, sugars and fatty acids in Cistus ladanifer, Cupressus lusitanica and Eucalyptus gunnii leaves. Ind. Crops Prod. 2009, 30, 427-430. [CrossRef]

10. Oliveira, L.; Cordeiro, N.; Evtuguin, D.V.; Torres, I.C.; Silvestre, A.J.D. Chemical composition of different morphological parts from 'Dwarf Cavendish' banana plant and their potential as a non-wood renewable source of natural products. Ind. Crops Prod. 2007, 26, 163-172. [CrossRef]

11. Sariyildiz, T. Interactions between litter quality, decomposition and soil fertility: A laboratory study. Soil Biol. Biochem. 2003, 35, 391-399. [CrossRef]

12. Sridhar, K.R.; Seena, S. Nutritional and antinutritional significance of four unconventional legumes of the genus Canavalia - A comparative study. Food Chem. 2006, 99, 267-288. [CrossRef]

13. Hsu, F.-L.; Chou, C.-J.; Chang, Y.-C.; Chang, T.-T.; Lu, M.-K. Promotion of hyphal growth and underlying chemical changes in Antrodia camphorata by host factors from Cinnamomum camphora. Int. J. Food Microbiol. 2006, 106, 32-38. [CrossRef]

14. Beleski-Carneiro, E. Structural and biological features of a hydrogel from seed coats of Chorisia speciosa. Phytochemistry 2002, 61, 157-163. [CrossRef]

15. Janaki, B.; Sashidhar, R.B. Physico-chemical analysis of gum kondagogu (Cochlospermum gossypium): A potential food additive. Food Chem. 1998, 61, 231-236. [CrossRef]

16. Benhura, M.A.N.; Chidewe, C. Some properties of a polysaccharide preparation that is isolated from the fruit of Cordia abyssinica. Food Chem. 2002, 76, 343-347. [CrossRef] 
17. Jacobs, A.; Kaiser, K.; Ludwig, B.; Rauber, R.; Joergensen, R.G. Application of biochemical degradation indices to the microbial decomposition of maize leaves and wheat straw in soils under different tillage systems. Geoderma 2011, 162, 207-214. [CrossRef]

18. Kakegawa, K.; Edashige, Y.; Ishii, T. Xyloglucan from xylem-differentiating zones of Cryptomeria japonica. Phytochemistry 1998, 47, 767-771. [CrossRef]

19. Naqvi, S.A.; Khan, M.M.; Shahid, M.; Jaskani, M.J.; Khan, I.A.; Zuber, M.; Zia, K.M. Biochemical profiling of mucilage extracted from seeds of different citrus rootstocks. Carbohydr. Polym. 2011, 83, 623-628. [CrossRef]

20. Elayoubi, F.A.; Fraser, A.; Jenkins, D.J.; Craig, P.S. Partial characterisation of carbohydrate-rich Echinococcus granulosus coproantigens. Int. J. Parasitol. 2003, 33, 1553-1559. [CrossRef]

21. Dungait, J.A.J.; Docherty, G.; Straker, V.; Evershed, R.P. Seasonal variations in bulk tissue, fatty acid and monosaccharide $\delta 13 \mathrm{C}$ values of leaves from mesotrophic grassland plant communities under different grazing managements. Phytochemistry 2010, 71, 415-428. [CrossRef] [PubMed]

22. Kompella, U.B.; Lee, V.H.L. Delivery systems for penetration enhancement of peptide and protein drugs: design considerations. Adv. Drug Deliv. Rev. 2001, 46, 211-245. [CrossRef]

23. Kajita, S.; Mashino, Y.; Nishikubo, N.; Katayama, Y.; Omori, S. Immunological characterization of transgenic tobacco plants with a chimeric gene for 4-coumarate:CoA ligase that have altered lignin in their xylem tissue. Plant Sci. 1997, 128, 109-118. [CrossRef]

24. Tverdislov, V.A.; Malyshko, E.V.; Il'chenko, S.A.; Zhulyabina, O.A.; Yakovenko, L.V. A periodic system of chiral structures in molecular biology. Biophysics 2017, 62, 331-341. [CrossRef]

25. Malyshko, E.V. On regularities in the spontaneous formation of structural hierarchies in chiral systems of nonliving and living matter. Phys.-Uspekhi 2019, 62, 354-363. [CrossRef]

26. Sidorova, A.E.; Malyshko, E.V.; Kotov, A.R.; Tverdislov, V.A.; Ustinin, M.N. Quantitative Criteria of Chirality in Hierarchical Protein Structures. Biophysics 2019, 64, 155-166. [CrossRef]

27. Zhou, Y.; Stuart-Williams, H.; Farquhar, G.D.; Hocart, C.H. The use of natural abundance stable isotopic ratios to indicate the presence of oxygen-containing chemical linkages between cellulose and lignin in plant cell walls. Phytochemistry 2010, 71, 982-993. [CrossRef] [PubMed]

28. Danso Marfo, T.; Datta, R.; Vranová, V.; Ekielski, A. Ecotone Dynamics and Stability from Soil Perspective: Forest-Agriculture Land Transition. Agriculture 2019, 9, 228. [CrossRef]

29. Marfo, T.D.; Datta, R.; Pathan, S.I.; Vranová, V. Ecotone Dynamics and Stability from Soil Scientific Point of View. Diversity 2019, 11, 53. [CrossRef]

30. Hussain, M.; Debnath, B.; Qasim, M.; Bamisile, B.S.; Islam, W.; Hameed, M.S.; Wang, L.; Qiu, D. Role of Saponins in Plant Defense Against Specialist Herbivores. Mol. Basel Switz. 2019, 24, 2067. [CrossRef]

31. Atkinson, N.J.; Dew, T.P.; Orfila, C.; Urwin, P.E. Influence of Combined Biotic and Abiotic Stress on Nutritional Quality Parameters in Tomato (Solanum lycopersicum). J. Agric. Food Chem. 2011, 59, 9673-9682. [CrossRef] [PubMed]

32. Constabel, C.P.; Major, I.T. Molecular Biology and Biochemistry of Induced Insect Defense in Populus. Recent Adv. Phytochem. 2005, 119-143.

33. Datta, R.; Kelkar, A.; Baraniya, D.; Molaei, A.; Moulick, A.; Meena, R.; Formanek, P. Enzymatic degradation of lignin in soil: A review. Sustainability 2017, 9, 1163. [CrossRef]

34. Milčevičová, R.; Gosch, C.; Halbwirth, H.; Stich, K.; Hanke, M.-V.; Peil, A.; Flachowsky, H.; Rozhon, W.; Jonak, C.; Oufir, M.; et al. Erwinia amylovora-induced defense mechanisms of two apple species that differ in susceptibility to fire blight. Plant Sci. 2010, 179, 60-67. [CrossRef]

35. Morsy, M.R.; Jouve, L.; Hausman, J.-F.; Hoffmann, L.; Stewart, J.M. Alteration of oxidative and carbohydrate metabolism under abiotic stress in two rice (Oryza sativa L.) genotypes contrasting in chilling tolerance. J. Plant Physiol. 2007, 164, 157-167. [CrossRef]

36. Wasano, N.; Konno, K.; Nakamura, M.; Hirayama, C.; Hattori, M.; Tateishi, K. A unique latex protein, MLX56, defends mulberry trees from insects. Phytochemistry 2009, 70, 880-888. [CrossRef]

37. Yancey, P.H. Compatible and Counteracting Solutes: Protecting Cells from the Dead Sea to the Deep Sea. Sci. Prog. 2004, 87, 1-24. [CrossRef]

38. Anjum, S.A.; Ashraf, U.; Tanveer, M.; Khan, I.; Hussain, S.; Shahzad, B.; Zohaib, A.; Abbas, F.; Saleem, M.F.; Ali, I.; et al. Drought Induced Changes in Growth, Osmolyte Accumulation and Antioxidant Metabolism of Three Maize Hybrids. Front. Plant Sci. 2017, 8, 69. [CrossRef] 
39. Meena, R.S.; Kumar, S.; Datta, R.; Lal, R.; Vijayakumar, V.; Brtnicky, M.; Sharma, M.P.; Yadav, G.S.; Jhariya, M.K.; Jangir, C.K. Impact of Agrochemicals on Soil Microbiota and Management: A Review. Land 2020, 9, 34. [CrossRef]

40. Ningthoujam, M.; Habib, K.; Bano, F.; Zutshi, S.; Fatma, T. Exogenous osmolytes suppresses the toxic effects of malathion on Anabaena variabilis. Ecotoxicol. Environ. Saf. 2013, 94, 21-27. [CrossRef]

41. Kampfraath, A.A.; Giesen, D.; van Gestel, C.A.; Le Lann, C. Pesticide stress on plants negatively affects parasitoid fitness through a bypass of their phytophage hosts. Ecotoxicology 2017, 26, 383-395. [CrossRef] [PubMed]

42. Edmond Ghanem, M.; Han, R.-M.; Classen, B.; Quetin-Leclerq, J.; Mahy, G.; Ruan, C.-J.; Qin, P.; Pérez-Alfocea, F.; Lutts, S. Mucilage and polysaccharides in the halophyte plant species Kosteletzkya virginica: Localization and composition in relation to salt stress. J. Plant Physiol. 2010, 167, 382-392. [CrossRef] [PubMed]

43. Vetter, J. Plant cyanogenic glycosides. Toxicon 2000, 38, 11-36. [CrossRef]

44. Sharma, A.; Shahzad, B.; Kumar, V.; Kohli, S.K.; Sidhu, G.P.S.; Bali, A.S.; Handa, N.; Kapoor, D.; Bhardwaj, R.; Zheng, B. Phytohormones Regulate Accumulation of Osmolytes Under Abiotic Stress. Biomolecules 2019, 9, 285. [CrossRef]

45. Vasconcelos, I.M.; Oliveira, J.T.A. Antinutritional properties of plant lectins. Toxicon 2004, 44, 385-403. [CrossRef]

46. Applebaum, S.W.; Gestetner, B.; Birk, Y. Physiological aspects of host specificity in the Bruchidae-IV. Developmental incompatibility of soybeans for Callosobruchus. J. Insect Physiol. 1965, 11, 611-616. [CrossRef]

47. De Geyter, E.; Swevers, L.; Soin, T.; Geelen, D.; Smagghe, G. Saponins do not affect the ecdysteroid receptor complex but cause membrane permeation in insect culture cell lines. J. Insect Physiol. 2012, 58, 18-23. [CrossRef]

48. kaur, M.; Singh, K.; Rup, P.J.; Saxena, A.K.; Khan, R.H.; Ashraf, M.T.; Kamboj, S.S.; Singh, J. A tuber lectin from Arisaema helleborifolium Schott with anti-insect activity against melon fruit fly, Bactrocera cucurbitae (Coquillett) and anti-cancer effect on human cancer cell lines. Arch. Biochem. Biophys. 2006, 445, 156-165. [CrossRef]

49. Silva, M.C.P.; Terra, W.R.; Ferreira, C. Absorption of toxic $\beta$-glucosides produced by plants and their effect on tissue trehalases from insects. Comp. Biochem. Physiol. B Biochem. Mol. Biol. 2006, 143, 367-373. [CrossRef]

50. Andrade-Cetto, A.; Vázquez, R.C. Gluconeogenesis inhibition and phytochemical composition of two Cecropia species. J. Ethnopharmacol. 2010, 130, 93-97. [CrossRef]

51. dos Santos, T.B.; Budzinski, I.G.F.; Marur, C.J.; Petkowicz, C.L.O.; Pereira, L.F.P.; Vieira, L.G.E. Expression of three galactinol synthase isoforms in Coffea arabica L. and accumulation of raffinose and stachyose in response to abiotic stresses. Plant Physiol. Biochem. 2011, 49, 441-448. [CrossRef] [PubMed]

52. Mandre, M.; Lukjanova, A. Biochemical and structural characteristics of Scots pine (Pinus sylvestris L.) in an alkaline environment. Est. J. Ecol. 2011, 60, 264. [CrossRef]

53. Ômura, H.; Honda, K. Feeding responses of adult butterflies, Nymphalis xanthomelas, Kaniska canace and Vanessa indica, to components in tree sap and rotting fruits: synergistic effects of ethanol and acetic acid on sugar responsiveness. J. Insect Physiol. 2003, 49, 1031-1038. [CrossRef] [PubMed]

54. Sengupta, S.; Mukherjee, S.; Parween, S.; Majumder, A.L. Galactinol synthase across evolutionary diverse taxa: Functional preference for higher plants? FEBS Lett. 2012, 586, 1488-1496. [CrossRef] [PubMed]

55. Schadel, C.; Blochl, A.; Richter, A.; Hoch, G. Short-term dynamics of nonstructural carbohydrates and hemicelluloses in young branches of temperate forest trees during bud break. Tree Physiol. 2009, 29, 901-911. [CrossRef]

56. Wróbel-Kwiatkowska, M.; Lorenc-Kukula, K.; Starzycki, M.; Oszmiański, J.; Kepczyńska, E.; Szopa, J. Expression of $\beta-1,3-$ glucanase in flax causes increased resistance to fungi. Physiol. Mol. Plant Pathol. 2004, 65, 245-256. [CrossRef]

57. Seifert, G.J. Nucleotide sugar interconversions and cell wall biosynthesis: how to bring the inside to the outside. Curr. Opin. Plant Biol. 2004, 7, 277-284. [CrossRef]

58. Badejo, A.A.; Fujikawa, Y.; Esaka, M. Gene expression of ascorbic acid biosynthesis related enzymes of the Smirnoff-Wheeler pathway in acerola (Malpighia glabra). J. Plant Physiol. 2009, 166, 652-660. [CrossRef] 
59. Watanabe, K.; Suzuki, K.; Kitamura, S. Characterization of a GDP-d-mannose 3",5"-epimerase from rice. Phytochemistry 2006, 67, 338-346. [CrossRef]

60. Bindschedler, L.V.; Tuerck, J.; Maunders, M.; Ruel, K.; Petit-Conil, M.; Danoun, S.; Boudet, A.-M.; Joseleau, J.-P.; Paul Bolwell, G. Modification of hemicellulose content by antisense down-regulation of UDP-glucuronate decarboxylase in tobacco and its consequences for cellulose extractability. Phytochemistry 2007, 68, 2635-2648. [CrossRef]

61. Minic, Z.; Jouanin, L. Plant glycoside hydrolases involved in cell wall polysaccharide degradation. Plant Physiol. Biochem. 2006, 44, 435-449. [CrossRef] [PubMed]

62. Karagiannis, E.; Michailidis, M.; Tanou, G.; Samiotaki, M.; Karamanoli, K.; Avramidou, E.; Ganopoulos, I.; Madesis, P.; Molassiotis, A. Ethylene -dependent and -independent superficial scald resistance mechanisms in "Granny Smith" apple fruit. Sci. Rep. 2018, 8, 11436. [CrossRef] [PubMed]

63. Loewus, F.A.; Murthy, P.P.N. myo-Inositol metabolism in plants. Plant Sci. 2000, 150, 1-19. [CrossRef]

64. Oomen, R.J.F.J.; Dao-Thi, B.; Tzitzikas, E.N.; Bakx, E.J.; Schols, H.A.; Visser, R.G.F.; Vincken, J.-P. Overexpression of two different potato UDP-Glc 4-epimerases can increase the galactose content of potato tuber cell walls. Plant Sci. 2004, 166, 1097-1104. [CrossRef]

65. Goulao, L.F.; Santos, J.; de Sousa, I.; Oliveira, C.M. Patterns of enzymatic activity of cell wall-modifying enzymes during growth and ripening of apples. Postharvest Biol. Technol. 2007, 43, 307-318. [CrossRef]

66. Gantulga, D.; Turan, Y.; Bevan, D.R.; Esen, A. The Arabidopsis At1g45130 and At3g52840 genes encode $\beta$-galactosidases with activity toward cell wall polysaccharides. Phytochemistry 2008, 69, 1661-1670. [CrossRef]

67. Monroe, J.D.; Garcia-Cazarin, M.L.; Poliquin, K.A.; Aivano, S.K. Antisense Arabidopsis plants indicate that an apoplastic $\alpha$-xylosidase and $\alpha$-glucosidase are encoded by the same gene. Plant Physiol. Biochem. 2003, 41, 877-885. [CrossRef]

68. Wu, G.; Bazer, F.W. Application of new biotechnologies for improvements in swine nutrition and pork production. J. Anim. Sci. Biotechnol. 2019, 10, 28. [CrossRef]

69. Hilz, H.; de Jong, L.E.; Kabel, M.A.; Verhoef, R.; Schols, H.A.; Voragen, A.G.J. Bilberry xyloglucan-novel building blocks containing $\beta$-xylose within a complex structure. Carbohydr. Res. 2007, 342, 170-181. [CrossRef]

70. Hsieh, Y.S.Y.; Harris, P.J. Structures of xyloglucans in primary cell walls of gymnosperms, monilophytes (ferns sensu lato) and lycophytes. Phytochemistry 2012, 79, 87-101. [CrossRef]

71. Deutschmann, R.; Dekker, R.F.H. From plant biomass to bio-based chemicals: Latest developments in xylan research. Biotechnol. Adv. 2012, 30, 1627-1640. [CrossRef] [PubMed]

72. Coutinho, P.M.; Andersen, M.R.; Kolenova, K.; vanKuyk, P.A.; Benoit, I.; Gruben, B.S.; Trejo-Aguilar, B.; Visser, H.; van Solingen, P.; Pakula, T. Post-genomic insights into the plant polysaccharide degradation potential of Aspergillus nidulans and comparison to Aspergillus niger and Aspergillus oryzae. Fungal Genet. Biol. 2009, 46, S161-S169. [CrossRef] [PubMed]

73. Kuivanen, J.; Biz, A.; Richard, P. Microbial hexuronate catabolism in biotechnology. AMB Express 2019, 9, 16. [CrossRef] [PubMed]

74. Cruz-Rus, E.; Botella, M.A.; Valpuesta, V.; Gomez-Jimenez, M.C. Analysis of genes involved in l-ascorbic acid biosynthesis during growth and ripening of grape berries. J. Plant Physiol. 2010, 167, 739-748. [CrossRef]

75. Sun, F.; Li, S.; He, D.; Cao, G.; Ni, X.; Tai, G.; Zhou, Y.; Wang, D. Effects of glycoalkaloids from Solanum plants on cucumber root growth. Phytochemistry 2010, 71, 1534-1538. [CrossRef]

76. Ali, B.H.; Ziada, A.; Blunden, G. Biological effects of gum arabic: A review of some recent research. Food Chem. Toxicol. 2009, 47, 1-8. [CrossRef]

77. O’Rourke, C.; Gregson, T.; Murray, L.; Sadler, I.H.; Fry, S.C. Sugar composition of the pectic polysaccharides of charophytes, the closest algal relatives of land-plants: presence of 3-O-methyl-D-galactose residues. Ann. Bot. 2015, 116, 225-236. [CrossRef]

78. Cleveland, L.; Coffman, R.E.; Coon, P.; Davis, L. Role of the copper in galactose oxidase. Biochemistry 1975, 14, 1108-1115. [CrossRef]

79. Oh, M.-M.; Trick, H.N.; Rajashekar, C.B. Secondary metabolism and antioxidants are involved in environmental adaptation and stress tolerance in lettuce. J. Plant Physiol. 2009, 166, 180-191. [CrossRef]

80. Cevallos-Cevallos, J.M.; Futch, D.B.; Shilts, T.; Folimonova, S.Y.; Reyes-De-Corcuera, J.I. GC-MS metabolomic differentiation of selected citrus varieties with different sensitivity to citrus huanglongbing. Plant Physiol. Biochem. 2012, 53, 69-76. [CrossRef] 
81. Ma, G.; Zhang, L.; Kato, M.; Yamawaki, K.; Asai, T.; Nishikawa, F.; Ikoma, Y.; Matsumoto, H.; Yamauchi, T.; Kamisako, T. Effect of electrostatic atomization on ascorbate metabolism in postharvest broccoli. Postharvest Biol. Technol. 2012, 74, 19-25. [CrossRef]

82. Boudet, A.M.; Kajita, S.; Grima-Pettenati, J.; Goffner, D. Lignins and lignocellulosics: A better control of synthesis for new and improved uses. Trends Plant Sci. 2003, 8, 576-581. [CrossRef]

83. Karg, S.R.; Kallio, P.T. The production of biopharmaceuticals in plant systems. Biotechnol. Adv. 2009, 27, 879-894. [CrossRef] [PubMed]

84. Rao, U.R.; Kwa, B.H.; Nayar, J.K.; Vickery, A.C. Brugia malayi and Brugia pahangi: Transmission blocking activity of ivermectin and brugian filarial infections in Aedes aegypti. Exp. Parasitol. 1990, 71, 259-266. [CrossRef]

85. Merivee, E.; Märtmann, H.; Must, A.; Milius, M.; Williams, I.; Mänd, M. Electrophysiological responses from neurons of antennal taste sensilla in the polyphagous predatory ground beetle Pterostichus oblongopunctatus (Fabricius 1787) to plant sugars and amino acids. J. Insect Physiol. 2008, 54, 1213-1219. [CrossRef] [PubMed]

86. Previato, J.O.; Mendonça-Previato, L.; Lewanczuk, R.Z.; Travassos, L.R.; Gorin, P.A.J. Crithidia spp.: Structural comparison of polysaccharides for taxonomic significance. Exp. Parasitol. 1982, 53, 170-178. [CrossRef]

87. Schnuch, M.; Hansen, K. Sugar sensitivity of a labellar salt receptor of the blowfly Protophormia terraenovae. J. Insect Physiol. 1990, 36, 409-417. [CrossRef]

88. Pendland, J.C.; Boucias, D.G. Hemagglutinin activity in the hemolymph of Anticarsiagemmatalis larvae infected with the fungus Nomuraearileyi. Dev. Comp. Immunol. 1985, 9, 21-30. [CrossRef]

89. Pyle, G.G.; Paaso, B.; Anderson, B.E.; Allen, D.D.; Marti, T.; Li, Q.; Siegel, M.; Khosla, C.; Gray, G.M. Effect of Pretreatment of Food Gluten with Prolyl Endopeptidase on Gluten-Induced Malabsorption in Celiac Sprue. Clin. Gastroenterol. Hepatol. 2005, 3, 687-694. [CrossRef]

90. Iida, T.; Hayashi, N.; Yamada, T.; Yoshikawa, Y.; Miyazato, S.; Kishimoto, Y.; Okuma, K.; Tokuda, M.; Izumori, K. Failure of d-psicose absorbed in the small intestine to metabolize into energy and its low large intestinal fermentability in humans. Metabolism 2010, 59, 206-214. [CrossRef]

91. Schwartz, R.M.; Furne, J.K.; Levitt, M.D. Paracellular intestinal transport of six-carbon sugars is negligible in the rat. Gastroenterology 1995, 109, 1206-1213. [CrossRef]

92. Levantovsky, R.; Allen-Blevins, C.R.; Sela, D.A. Nutritional Requirements of Bifidobacteria. Bifidobact. Relat. Org. 2018, 115-129.

93. Vranova, V.; Rejsek, K.; Formanek, P. Aliphatic, cyclic, and aromatic organic acids, vitamins, and carbohydrates in soil: A review. Sci. World J. 2013, 2013, 524239. [CrossRef] [PubMed]

94. Raymer, G.S.; Hartman, D.E.; Rowe, W.A.; Werkman, R.F.; Koch, K.L. An open-label trial of L-glucose as a colon-cleansing agent before colonoscopy. Gastrointest. Endosc. 2003, 58, 30-35. [CrossRef]

95. Rogers, B.F.; Tate, R.L. Temporal analysis of the soil microbial community along a toposequence in Pineland soils. Soil Biol. Biochem. 2001, 33, 1389-1401. [CrossRef]

96. Ojha, A.K.; Maiti, D.; Chandra, K.; Mondal, S.; Roy, D.D.S.K.; Ghosh, K.; Islam, S.S. Structural assignment of a heteropolysaccharide isolated from the gum of Cochlospermum religiosum (Katira gum). Carbohydr. Res. 2008, 343, 1222-1231. [CrossRef]

97. Rana, V.; Kumar, V.; Soni, P.L. Structural characterization of an acidic polysaccharide from Dalbergia sissoo Roxb. leaves. Carbohydr. Polym. 2012, 90, 243-250. [CrossRef]

98. Laver, M.L.; Chen, C.-H.; Zerrudo, J.V.; Lai, Y.-C.L. Carbohydrates of the inner bark of Pseudotsuga menziesii. Phytochemistry 1974, 13, 1891-1896. [CrossRef]

99. Carlsson, H.E.; Sundblad, G.; Hammarström, S.; Lönngren, J. Structure of some oligosacharides derived from rat-intestinal glycoproteins. Carbohydr. Res. 1978, 64, 181-188. [CrossRef]

100. Berman, E. Determination of the structure of three oligosaccharides from normal human urine by using 60-MHz, Carbon-13 nuclear magnetic resonance spectroscopy. Carbohydr. Res. 1983, 118, 9-20. [CrossRef]

101. Cheng, H.; Wang, B.; Lv, J.; Jiang, M.; Lin, S.; Deng, Z. Xylitol production from xylose mother liquor: A novel strategy that combines the use of recombinant Bacillus subtilis and Candida maltosa. Microb. Cell Factories 2011, 10, 5. [CrossRef] [PubMed]

102. Lemonnier, M.; Fournet, B.; Bourillon, R. Isolation and characterization of monofucosyl monosialyl derivative of lacto N-neohexaose obtained from human pregnancy urine. Biochem. Biophys. Res. Commun. 1977, 77, 767-774. [CrossRef] 
103. Chookaew, T.; O-Thong, S.; Prasertsan, P. Fermentative production of hydrogen and soluble metabolites from crude glycerol of biodiesel plant by the newly isolated thermotolerant Klebsiella pneumoniae TR17. Int. J. Hydrog. Energy 2012, 37, 13314-13322. [CrossRef]

104. Datta, R.; Vranová, V.; Pavelka, M.; Rejšek, K.; Formánek, P. Effect of soil sieving on respiration induced by low-molecular-weight substrates. Int. Agrophysics 2014, 28, 119-124. [CrossRef]

105. Zheng, H.; Ouyang, Z.Y.; Wang, X.K.; Fang, Z.G.; Zhao, T.Q.; Miao, H. Effects of regenerating forest cover on soil microbial communities: A case study in hilly red soil region, Southern China. For. Ecol. Manag. 2005, 217, 244-254. [CrossRef]

106. Garland, J.L. Patterns of potential C source utilization by rhizosphere communities. Soil Biol. Biochem. 1996, 28, 223-230. [CrossRef]

107. Pathan, S.I.; Větrovský, T.; Giagnoni, L.; Datta, R.; Baldrian, P.; Nannipieri, P.; Renella, G. Laura Giagnoni, Rahul Datta, Petr Baldrian, Paolo Nannipieri, Giancarlo Renella Microbial expression profiles in the rhizosphere of two maize lines differing in N use efficiency. Plant Soil 2018, 433, 401-413. [CrossRef]

108. Yadav, G.; Datta, R.; Imran Pathan, S.; Lal, R.; Meena, R.; Babu, S.; Das, A.; Bhowmik, S.; Datta, M.; Saha, P. Effects of Conservation Tillage and Nutrient Management Practices on Soil Fertility and Productivity of Rice (Oryza sativa L.)-Rice System in North Eastern Region of India. Sustainability 2017, 9, 1816. [CrossRef]

109. Castillo, M.A.; Felis, N.; Aragón, P.; Cuesta, G.; Sabater, C. Biodegradation of the herbicide diuron by streptomycetes isolated from soil. Int. Biodeterior. Biodegrad. 2006, 58, 196-202. [CrossRef]

110. Saibi, W.; Gargouri, A. Hydroxyl distribution in sugar structure and its contributory role in the inhibition of Stachybotrys microspora $\beta$-glucosidase (bglG). Carbohydr. Res. 2011, 346, 1848-1854. [CrossRef]

111. El-Ashry, E.-S.H.; El Nemr, A. Synthesis of mono- and di-hydroxylated prolines and 2-hydroxymethylpyrrolidines from non-carbohydrate precursors. Carbohydr. Res. 2003, 338, 2265-2290. [CrossRef]

112. Datta, R.; Baraniya, D.; Wang, Y.-F.; Kelkar, A.; Meena, R.; Yadav, G.; Teresa Ceccherini, M.; Formanek, P. Amino Acid: Its Dual Role as Nutrient and Scavenger of Free Radicals in Soil. Sustainability 2017, 9, 1402. [CrossRef]

113. Kaci, Y.; Heyraud, A.; Barakat, M.; Heulin, T. Isolation and identification of an EPS-producing Rhizobium strain from arid soil (Algeria): characterization of its EPS and the effect of inoculation on wheat rhizosphere soil structure. Res. Microbiol. 2005, 156, 522-531. [CrossRef] [PubMed]

114. Dastager, S.G.; Deepa, C.K.; Pandey, A. Isolation and characterization of novel plant growth promoting Micrococcus sp. NII-0909 and its interaction with cowpea. Plant Physiol. Biochem. 2010, 48, 987-992. [CrossRef] [PubMed]

115. Datta, R.; Anand, S.; Moulick, A.; Baraniya, D.; Pathan, S.I.; Rejsek, K.; Vranova, V.; Sharma, M.; Sharma, D.; Kelkar, A.; et al. How enzymes are adsorbed on soil solid phase and factors limiting its activity: A Review. Int. Agrophysics 2017, 31, 287-302. [CrossRef]

116. Molaei, A.; Lakzian, A.; Datta, R.; Haghnia, G.; Astaraei, A.; Rasouli-Sadaghiani, M.; Ceccherini, M.T. Impact of chlortetracycline and sulfapyridine antibiotics on soil enzyme activities. Int. Agrophysics 2017, 31, 499-505. [CrossRef]

117. Molaei, A.; Lakzian, A.; Haghnia, G.; Astaraei, A.; Rasouli-Sadaghiani, M.; Ceccherini, M.T.; Datta, R. Assessment of some cultural experimental methods to study the effects of antibiotics on microbial activities in a soil: An incubation study. PLoS ONE 2017, 12, e0180663. [CrossRef]

118. Vidanarachchi, J.K.; Iji, P.A.; Mikkelsen, L.L.; Sims, I.; Choct, M. Isolation and characterization of water-soluble prebiotic compounds from Australian and New Zealand plants. Carbohydr. Polym. 2009, 77, 670-676. [CrossRef]

119. Zhang, Z.; Srichuwong, S.; Kobayashi, T.; Arakane, M.; Park, J.; Tokuyasu, K. Bioconversion of l-arabinose and other carbohydrates from plant cell walls to $\alpha$-glucan by a soil bacterium, Sporosarcina sp. N52. Bioresour. Technol. 2010, 101, 9734-9741. [CrossRef]

120. Brtnicky, M.; Dokulilova, T.; Holatko, J.; Pecina, V.; Kintl, A.; Latal, O.; Vyhnanek, T.; Prichystalova, J.; Datta, R. Long-term effects of biochar-based organic amendments on soil microbial parameters. Agronomy 2019, 9, 747. [CrossRef]

(C) 2020 by the authors. Licensee MDPI, Basel, Switzerland. This article is an open access article distributed under the terms and conditions of the Creative Commons Attribution (CC BY) license (http://creativecommons.org/licenses/by/4.0/). 